\title{
CARTOGRAFIAS DE PESQUISA E CURRÍCULOS QUE MOVIMENTAM OS CORPOS NA EDUCAÇÃO INFANTIL
}

\author{
Ana Cláudia Santiago Zouain ${ }^{1}$ \\ Larissa Ferreira Rodrigues Gomes ${ }^{2}$
}

\section{CAMINHOS INICIAIS DE PESQUISA E A COMPOSIÇÃO DE UM CORPO COLETIVO EM DEVIR}

O desejo que impulsionou essa escrita foi sendo produzido pelos bons encontros com os espaços-tempos da Educação Infantil. Em meio aos movimentos de vida que pulsam na escola, afetamos e fomos afetados. Nossos corpos vibravam no encontro com outros corpos. E, nessa rede de afetos, compomos um corpo coletivo com crianças e professores "praticantes" (CERTEAU, 1996) desse cotidiano.

De acordo com Carvalho (2009), mediante os estudos de Espinosa, nos cotidianos escolares vivenciamos bons e maus encontros que aumentam ou diminuem a nossa potência de agir. Escolhemos, então, produzir a pesquisa em um Centro Federal de Educação Infantil, pois foi com esse espaço-tempo que nos lançamos aos afetos, às alegrias, às tristezas, aos choros, ao calor, ao dançar dos corpos, à inventividade, aos movimentos de pensamento, que nos fazem acreditar que há muita vida sendo vivida e praticada na escola.

Na tentativa de praticar uma cartografia sentimental (ROLNIK, 2007) de pesquisa com os cotidianos escolares, nosso corpo se envolveu especificamente com os corpos das crianças. Elas são

\footnotetext{
${ }^{1}$ Mestre em Educação pelo Programa de Pós-Graduação de Mestrado Profissional em Educação da Universidade Federal do Espírito Santo - PPGMPE/UFES, na linha de Docência e Gestão de Processos educativos. Área de concentração: Currículos, Cotidianos, Subjetividades e Formação de Professores. Atua na UFES como pesquisadora - Bolsista FAPES (2017 - atual).

2 Doutora em Educação (Universidade Federal do Espírito Santo/UFES), Mestre em Educação (Universidade Federal do Espírito Santo/UFES) na linha de pesquisa "Cultura, currículo e formação de educadores". Possui Licenciatura Plena em Educação Física (Universidade Federal do Espírito Santo/UFES) e Licenciatura em Pedagogia (ISEAT). Atualmente é professora da Educação Básica Técnica e Tecnológica na UNIVERSIDADE FEDERAL DO ESPÍRITO SANTO, no Centro de Educação Infantil CRIARTE e professora do Programa de Pós Graduação de Mestrado Profissional em Educação (PPGMPE/UFES). Coordenadora do grupo de pesquisa do CNPQ Currículos, culturas juvenis e produção de subjetividades.
} 
sedentas de toque, rastreiam novidades, curiosidades, percorrem rotas de fuga, não tem critérios para a produção de experiências, basta serem afetadas.

Dessa maneira, fomos lançados na plenitude das cenas cotidianas, não só capturando, mas também compondo sentidos. A pesquisa se deu em meio aos processos, possuindo "múltiplas entradas e não segue um caminho unidirecional" (KASTRUP, 2015, p. 43).

O que importava para nós, não era formular práticas novas para as ações pedagógicas, mas desencadear imagens e conceitos que considerassem a criança como produtora de pensamento. Ressaltando a aposta no "devir-criança" (DELEUZE; GUATTARI, 1997), para pensar práticas fluidas e inventivas de currículos e de docências. Assim, reconhecemos a criança enquanto compositora e transcriadora de imagens que movimentam o nosso pensamento.

O conceito de devir-criança foi desenvolvido por Deleuze e Guattari compreendido "como fissura, ruptura na lógica temporal onde nasce-se bebê, depois torna-se criança, depois adulto e assim sucessivamente. O conceito de devir nada tem a ver com o que virá, e é nesse sentido que ele é aqui advogado como linha de fuga" (TEBET, 2017, p. 146).

Desse modo, escolhemos compor com imagens cinema (DELEUZE, 2007) e com imagens escolas (RODRIGUES, 2015) produzidas pelas/com as crianças e professores e pesquisadora como possibilidade de colorir currículos, docências e infâncias pela pluralidade de ideias. As imagens escolas foram cartografadas nos processos curriculares, nos movimentos docentes, nas experimentações pedagógicas, nos encontros com as crianças, enfim, entre a banalidade vital do cotidiano.

Apostamos, assim, no aporte teórico-metodológico da pesquisa cartográfica, pois nossa pesquisa não se destinou a uma coleta de dados, mas uma produção coletiva de dados em composição com o campo problemático do estudo que se desdobrou no seguinte questionamento: Que imagens de currículos têm sido produzidas em nossas escolas? Para tanto, objetivamos entender em que sentido a produção de imagens cinema com crianças e professores provoca composição de territórios existenciais para os currículos na Educação Infantil.

Um dos desafios encontrados foi o de distanciar a pesquisa do uso do cinema como disparador de conteúdos, apenas para reforçar o que é transmitido em sala de aula, para pedagogizar. Buscamos descontruir a imagem do cinema como mera representação de imagens ou do uso de filmes somente para entretenimento, não que esse movimento não seja considerado, mas não é a intenção da pesquisa. O interessante, como afirma Deleuze (2007, p. 29), é “o cinema se tornando não mais empresa de reconhecimento, mas de conhecimento". 
Com base em Deleuze (2007), mobilizamos a teoria do cinema como um modo de pensamento. Compreendemos que "o cinema é uma força que nos leva ao movimento do pensar, que propicia encontros, experiências, que nos possibilita a surpresa, o choque, o silêncio, a indagação, permitindo habitar outros/novos territórios ainda não sentidos e vividos" (CARVALHO; SILVA, 2014, p. 90).

Entendemos ainda que "pensar é explicar, desenvolver, decifrar, traduzir signos" (VASCONCELLOS, 2005, p. 1220). Assim, importa-nos também a relação entre pensamento e a tradução dos signos que se movem em meio à vida escolar. Em Proust e os signos, Deleuze (1987) provoca a atenção para os signos artísticos que potencializam a experimentação de outras dimensões estéticas.

Entramos nas redes de afetos com crianças e professores e demais praticantes desse espaçotempo. Pertencemos a diferentes territórios que até então não habitávamos e nos deixamos levar por esse campo coletivo de forças (BARROS; KASTRUP, 2015). Nesse sentido, entendemos que "há um coletivo se fazendo com a pesquisa, há uma pesquisa se fazendo com o coletivo" (BARROS; KASTRUP, 2015, p. 73).

Praticamos a cartografia sem a pretensão de propor verdades, mas com a intenção de acompanhar os movimentos do cotidiano escolar (LOURENÇO, 2015). Desejamos capturar a potência das experimentações desse espaço-tempo e com "essa atenção flutuante, nos colocamos abertos aos acontecimentos e concentrados por meio de nosso corpo vibrátil que nos sensibiliza a produzir sentidos" (LOURENÇO, 2015, p. 58).

Durante os procedimentos investigativos foram realizados como estratégias metodológicas para a produção de dados a observação participante, a aposta nas "redes de conversações" (CARVALHO, 2009) entre crianças e professores e os registros em diário de campo nos quais os dados eram colocados por escrito e também gravados e/ou filmados para que depois fossem transcritos. Escolhemos compor com redes de conversações, pois se configuram na produção de sentidos. Envolvem discursos, textos, narrativas, imagens, sons, encontros, silêncios e silenciamentos,... (CARVALHO, 2009).

O diário de campo foi feito de modo virtual, seguindo a fluidez dos espaços e tempos que percorríamos. Assim, usamos um celular para registrar a vida e narrativas que se configuraram como "processos narrativosimagéticos” da pesquisa (RODRIGUES, 2015). Segundo Rodrigues (2015, p. 56), esse termo é um “conceito ‘roubado' de Parente (2013), pelo qual a compreensão sobre imagem e/ou narrativa está na ordem do acontecimento, entendendo a narrativa e a imagem como 
acontecimento e não apenas tomando-as como representação”. A narrativa é constituída como sentido e tomada como imagem de pensamento.

Desse modo, nosso diário de campo "evoca as zonas de lembranças" (RODRIGUES, 2015, p. 57), ao compor com processos narrativosimagéticos cartografados nos encontros da pesquisa. Tecem imagens reais-virtuais, por isso, os diários são "recursos valiosos do cotidiano escolar" (SANTOS; DIAS, 2016, p. 319), relacionam-se aos acontecimentos.

Nesse movimento, os processos narrativosimagéticos cartografados por essa pesquisa se configuram por encontros com imagens que movimentam o pensamento. Esses processos não foram identificados ou definidos, pois "entre imagens não se pode efetivamente dizer o que é real ou imaginário, na mistura do atual com o virtual, o mundo se multiplica e falsifica as identidades e a produção de verdades, ou seja, a fabulação ocorre” (RODRIGUES, 2015, p. 57).

A cartografia "fabular-se-á, portanto, a partir da escolha pelo lócus da pesquisa" (RODRIGUES, 2015, p. 57). Escolhemos compor o estudo em um Centro Federal de Educação Infantil localizado no bairro Goiabeiras, munícipio de Vitória.

Diante disso, a relevância deste estudo para o campo da Educação, especificamente para a Educação Infantil, está na valorização das redes de afetos experienciadas entre crianças e professores e potencializadas pelos encontros entre as imagens cinema e os devires infantis. Portanto, aponta-se o desejo de produzir outras imagens de infância, de currículo e de docência na concepção da escola como uma comunidade de afetos (CARVALHO, 2009) ao considerar aprendizagens intensivas e inventivas.

\section{ENTRE CURRÍCULOS ACONTECIMENTO QUE ATRAVESSAM OS TERRITÓRIOS ESCOLARES}

Desejamos pensar currículo nos múltiplos enredamentos que atravessam o território escolar, nos distanciando "de sua representação fixa/definitiva, indo ao encontro de sua condição de fluxo, de redes, de nomadismo, de composições e deslizamentos, [...], fazendo vazar toda e qualquer possibilidade de um significado fixo ou de um determinismo conceitual” (FERRAÇO, 2017, p. 535).

Currículos como acontecimento. Sem prescrição, acontecem, insurgem, irrompem nos cotidianos escolares. Estabelecem-se nas fronteiras, nas dobras do macro e do micro, simultaneamente, "na medida em que não podemos, nunca, exercer absoluto controle sobre os acontecimentos" (GALLO, 2007, p. 21). 
Para tanto, entramos em composição com os corpos da Educação Infantil na tentativa de compor currículos acontecimento. Optamos por escrever currículos no plural, pois entendemos que são diferentes processos atravessados por forças dominantes, mas também produzidos pelos corposforças de seus praticantes - ressaltamos aqui crianças e professores - em meio aos encontros compartilhados com os cotidianos escolares. Como podemos observar na narrativa que se segue:

"Existem muitas dúvidas em relação ao currículo da educação infantil, por muito tempo sempre foi visto como um preparatório para o ensino fundamental com atividades que priorizavam a motricidade e as habilidades manuais, entretanto acredito que em muitos lugares essas práticas ainda são utilizadas, mas com a chegada dos novos materiais e de pesquisas na área, o currículo para educação infantil foi ampliando, priorizando as brincadeiras e as interações das crianças com o mundo. Assim acredito que na prática exista essa variedade de currículos sendo praticados", fala de uma professora do grupo cinco.

No desejo de provocar o pensamento acerca dos processos curriculares enquanto acontecimentos, contamos com Dias (2011) ao afirmar que os movimentos nos passam e nos atravessam com uma passagem de vida, como aberturas a outros possíveis...

[...] Aquilo que nos acontece, Aquilo que nos passa, Aquilo que nos sucede,

Aquilo que se processa como uma passagem de vida, Que atravessa o vivível e o vivido (DIAS, 2011, p. 285).

Buscamos criar outros possíveis no campo do território escolar, não para renová-lo ou refazêlo, mas como uma abertura aos encontros. Isso não quer dizer que o mundo dos possíveis seja isolado das organizações e dos movimentos estanques. O possível "não é uma categoria abstrata que designa qualquer coisa que não existe" (LAZZARATO, 2006, p. 25), mas se configura por movimentos insurgentes que resistem às padronizações ao tecerem agenciamentos coletivos com o outro do pensamento.

Em meio a esses agenciamentos coletivos que se produzem nos cotidianos escolares, entendemos que o currículo é constituído "por tudo aquilo que é vivido, sentido, praticado no âmbito escolar e que está colocado na forma de documentos escritos, conversações, sentimentos e ações concretas vividas/praticadas pelos praticantes do cotidiano" (CARVALHO, 2009, p. 179).

O acontecimento, então, é da ordem do acaso, imprevisível, não sendo possível perguntar o seu sentido, pois ele é o próprio sentido (DELEUZE; GUATTARI, 2007). Os currículos acontecimento se configuram nas formas-forças cotidianas, se repetindo e se diferenciando nas multiplicidades das redes, buscando sua potência nos "fenômenos fronteiriços" (DELEUZE; GUATTARI, 2007) que cruzam o território escolar. 
Posto isso, ao adentrarmos o espaço-tempo escolar compomos um corpo coletivo de forças que atua em articulação com as forças que ali existem. "Seria o mesmo que dizer que na vida tudo é questão de forças? Sim, se compreendermos que a relação de forças não é quantitativa, mas necessariamente implica certas "qualidades"” (DELEUZE, 2007, p. 171). Somos corpos-forças no encontro com outras forças que ao afetarmos, nos afetam, essa é a potência da vida.

Como corpos-forças em relação, habitamos diferentes planos que se articulam entre si. Segundo Maurizio Lazzarato (2006), um plano é “imposto pelas instituições constituídas, no qual tudo se passa como se houvesse um só mundo possível” (LAZZARATO, 2006, p. 203-204); e o outro plano é constituído "pelos movimentos e pelas singularidades, que é o mundo da criação e da efetuação de uma multiplicidade de mundos possíveis" (idem).

Não nos coube nessa pesquisa impor um plano em detrimento de outro, pois ambos se correlacionam nos territórios escolares, bem como na vida em um todo. O que nos interessou ao nos relacionarmos com esses planos foi a possibilidade de criar movimentos intercambiáveis entre eles.

Tecemos currículos entre um conjunto de forças molares que tem se consolidado na tentativa de emoldurar o currículo em uma única prática possível, (pensado como um modelo a ser seguido, como uma organização de conteúdos, aprendizagens e competências que precisam ser dominadas por seus praticantes), e entre os processos de resistência de um currículo acontecimento vivido e praticado nos cotidianos escolares, como "fluxo e não apenas como forma, ou produto que pode ser objetificado e comercializado. Apostamos na ideia de currículo como intensidades produzidas em meio às relações de poder" (FERRAÇO, 2017, p. 535).

"Podemos pensar os processos curriculares para além dos textos normativos na medida
em que compreendemos formação humana como um processo, de idas e vindas e
contraditório; como um processo inter-relacionado ao contexto social e como uma
"prática de liberdade" (Paulo Freire). Uma compreensão mais alargada nessa direção
nos favorece superar as prescrições dos documentos e problematizá-los", fala de uma
professora do grupo cinco.

Ao nos envolvermos com o território escolar, transitamos pelos regimes de organização e de criação que ali circulam. Compomos diferentes imagens escola que se tecem em descrições orgânicas e cristalinas. As imagens escola orgânicas supõem uma realidade preexistente, "servem para definir situações sensório-motoras" (DELEUZE, 2007, p. 155-156), são definidas pelas linhas impositivas e habituais que nos conduzem a uma ação determinada. Como podemos perceber pela narrativa abaixo:

\footnotetext{
"Atualmente estamos sofrendo com a pressão da alfabetização das crianças, (se referindo à Política Nacional de Alfabetização pelo método fônico), assim tenho percebido uma exagerada valorização de um aspecto que é a linguagem oral e escrita", crítica de uma professora do grupo cinco.
} 
A crítica da professora aponta uma imagem de currículo pragmática, conteudista, que é fortemente pressionada nas escolas pelos sistemas de ensino. Mas, o cotidiano também é composto pelas imagens cristalinas que "remetem a situações puramente óticas e sonoras desligadas de seu prolongamento motor" (DELEUZE, 2007, p. 156). Imagens escolas cristalinas dão passagem à multiplicidade de vida, ao acontecimento. Articulam dois modos de existência em um "circuito em que o real e o imaginário, o atual e o virtual, correm um atrás do outro, trocam de papel e se tornam indiscerníveis" (idem).

"Entretanto, ainda existem currículos baseados nas descobertas e práticas inventivas da infância" - continuou a professora.

Os currículos acontecimento perpassam as imagens orgânicas e cristalinas, na composição de linhas diversas que se metamorfoseiam entre si. A produção do pensamento se tece nos encontros de crianças e professores na configuração de currículos que movimentam os corpos.

Desse modo, se faz necessário questionar os contextos políticos atuais da Educação brasileira, ao passo que, legitimou em dezembro de 2017 a BNCC, visando homogeneizar os saberes, os currículos e os processos avaliativos da Educação Básica. Como o próprio documento propõe:

[...] um documento de caráter normativo que define o conjunto orgânico e progressivo de aprendizagens essenciais que todos os alunos devem desenvolver ao longo das etapas e modalidades da Educação Básica, de modo a que tenham assegurados seus direitos de aprendizagem e desenvolvimento (BRASIL, 2017, p. 7).

Homologada para ser a "referência nacional para a formulação dos currículos dos sistemas e das redes escolares dos Estados, do Distrito Federal e dos Municípios e das propostas pedagógicas das instituições escolares" (BRASIL, 2017, p. 8), a BNCC delimita os processos pedagógicos referentes à formação de professores, à avaliação, à seleção dos conteúdos, a fim de garantir "um patamar comum de aprendizagens a todos os estudantes, tarefa para qual a BNCC é instrumento fundamental" (idem).

A Educação Infantil, primeira etapa da Educação Básica, também integra o documento por uma base comum, fazendo-se necessário discutir as interferências nos processos de aprender e ensinar nesta etapa de ensino. Portanto, nossas cartografias escolares se deslizaram por essas imagens escolas que foram impostas por institucionalizações dogmáticas de pensamento e por imagens de currículos que movimentam os corpos ao se entrelaçarem com outras possibilidades de ser/fazer/pensar/habitar a escola.

A pesquisa se fez nesse deslocamento de um só mundo possível para uma multiplicidade de acontecimentos. Como afirma Lazzarato (2006, p. 13), "as novas possibilidades de vida entram em 
choque com os poderes organizados e constituídos, mas também com aquilo que estes mesmos poderes tentam organizar a partir da abertura constituinte". Assim, trilhamos as fronteiras macro/micropolíticas, desdobrando processos curriculares pela repetição e diferença de práticas diversas, que por serem complexas, potencializam os currículos.

Ou seja, sem desconsiderar a importância das discussões e análises que são realizadas no âmbito do próprio texto governamental, defendemos a necessidade de, com nossas pesquisas, fortalecer os movimentos de resistência e de escape que acontecem na microfísica dos cotidianos escolares, nos diferentes espaçostempos intersticiais das escolas, (FERRAÇO, 2017, p. 544).

Entre. Interstício. Composição. Currículos. Texto. Práticas. Praticantes. Culturas. Subjetividades. Significantes. Acontecimentos. Dobras... Para Carvalho (2009), no cotidiano escolar, estamos inseridos numa formação sociocultural que produzimos, mas somos também, por ela produzidos. Carregamos conosco as redes de subjetividades que são constituídas pelas inúmeras relações que estabelecemos em nossos ambientes sociais. Portanto, se faz necessário compreender a escola como um campo de possibilidades aberto aos saberes e às diferenças.

Tal concepção se coloca contrária à ideia de uma base que busca "contribuir para o alinhamento de outras políticas e ações” (BRASIL, 2017, p. 8) a fim de garantir que sua intencionalidade seja alcançada por uma suposta qualidade de educação em prol de um comum idealizado. Mas, o que pode ser considerado como "comum" a todos? Quem o determinou? A quem esse comum interessa? Essas e tantas outras perguntas nos instigam quando nos deparamos com esse tipo de documento unificador de currículos em um único sentido comum.

Essas problematizações traçam uma rede de novas articulações e de desejos que ampliam e diminuem suas intensidades, deixando marcas no cenário educativo e político brasileiro, apontando que um outro mundo é possível se efetuar. Nesse sentido, consideramos como Lazzarato (2006), que são as problematizações que produzem o acontecimento (GOMES; GOMES, 2018, p. 16).

Impulsionados com as problematizações-acontecimento que nos cercam, questionamos "de quem é o currículo?” (GOMES; GOMES, 2018), para indagar imagens escola submissas a uma força 'comum' dominante. Por isso, movemos o pensamento com a produção de imagens inventivas de currículos que se estabelecem na contramão do que se espera tanto pela BNCC, quanto ainda pelo poder dominante que cerca o currículo. Compreendemos que o comum não "vem a ser o consenso, ou seja, adesão e alienação e/ou identificação como um representante "porta-voz" de uma posição comum ou de uma posição metafísica universal” (CARVALHO, 2009, p. 162).

Ao apostarmos nos cotidianos escolares na perspectiva da filosofia da diferença, toda afirmação de vida é considerada, tanto nos modos de ser/fazer/pensar os sujeitos quanto os 
conhecimentos. Entendemos que o comum é "construído pelo reconhecimento do outro, por uma relação com o outro, porque as redes de subjetividades e/ou a "multidão" são constituídas por uma série de elementos que objetivamente estão em circulação e que constituem o comum" (CARVALHO, 2009, p. 162).

Compreendemos a "constituição do "comum" como algo que acontece na e em relação" (CARVALHO, 2009, p. 163). O território escolar é povoado por um coletivo que compõe um corpo comum constituído em suas diferenças. "Portanto, pode-se dizer que não existe escola, mas escolas" (idem). O que nos move é a noção de uma “comunalidade expansiva" (CARVALHO, 2009). Habitamos e agimos com o território da pesquisa ao mesmo tempo em que configuramos um corpo comum coletivo que se tece nas relações, nos agenciamentos das forças e na criação de outros possíveis.

O desejo de problematização que portamos não é individual, ele é movido por um coletivo de forças. Somos compostos por diferentes imagens daquilo que nos afetou em um dado momento em nossos encontros. De modo que, ao habitarmos um território, carregamos conosco imagens virtuais de outras paisagens já experimentadas que tendem a se atualizar em nós. Então, não há como falar de uma única imagem curricular possível, como a que predomina a imagem escola por uma perspectiva hegemônica moderna, centrada em práticas únicas e igualitárias. Mas, buscamos compor com imagens errantes que se produzem com os acontecimentos imprevisíveis dos currículos.

De modo geral, em meio aos cotidianos da Educação Infantil, problematizamos currículos com crianças e professores pela criação de possibilidades para além de um comum quantificado. Os currículos acontecem entre os movimentos compartilhados com os praticantes. Destacamos os processos curriculares experimentados entre imagens cinema e imagens escola.

Com as crianças, exploramos currículos ao produzir conhecimentos tecidos em redes de afetos com as imagens cinema. Nesse encontro, questionamos a realidade imagética, produzimos sentidos individuais e coletivos, traçamos linhas de fuga e estabelecemos redes de conversações por meio da potência das imagens. Da mesma maneira, professores permitiram uma abertura de suas práticas pedagógicas ao proporcionarem imagens curriculares em diferentes espaços-tempos escolares:

"Acredito que o processo criativo se faz quando as concepções que embasam o trabalho pedagógico potencializam a superação do "sempre mesmo". Também a autonomia docente é fundamental tendo em vista que favorece a inventividade, o levantamento de ideias junto das crianças, a construção de propostas de trabalho que acolham as necessidades e desejos dos sujeitos envolvidos no processo formativo", narrativa de uma professora do grupo cinco. 
Nesse processo de afetação dos corpos, as imagens cinema emergiram possibilidades de currículos acontecimento enquanto linhas flexíveis que escapam a linearidade habitual do território escolar. O encontro das crianças com as imagens cinema provocaram a composição de imagens escola pelas quais o pensamento de crianças e professores foram impulsionados a criar...

"Oba! Hoje tem cinema" - disse uma criança.

"Eu vou chegar primeiro" - disse outra enquanto corria pra fila.

Entramos na sala de vídeo, o filme vai começar, olhares e ouvidos atentos... As redes de conversações já estão acontecendo. O que é aquilo? Uma criança não se aguenta parada, precisa levantar, precisa falar. As outras pedem silêncio, “quero ouvir!”, “Shiu!” A professora coloca a criança de volta ao seu lugar. Ela levanta novamente. Um menino que não para...

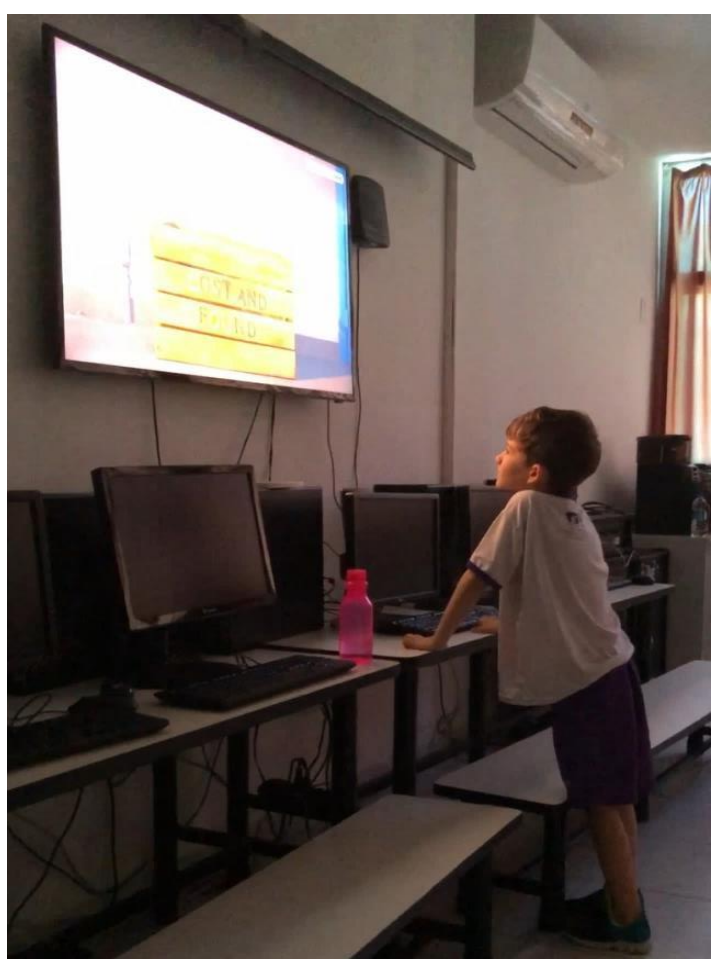

Imagem 1 - O menino que não para movimenta seu corpo no embalo do cinema. Fonte: arquivo pessoal.

As crianças no encontro com as imagens cinema engendram imagens escola insurgentes que distanciam os corpos de um assujeitamento linear. Os currículos acontecimento são produzidos em meio aos movimentos incansáveis e inventivos de crianças e professores que giram seus pensamentos com o cinema, libertando-os de um modelo de verdade para se lançarem na produção de imagens cristalinas. 
O acontecimento nos passa e nos provoca a uma ação não determinada. Somos movidos pelas afecções que tocam nossos corpos e nos impulsionam a uma potência de agir impensada que se configura pela experimentação afetiva. Então, a desordem de um acontecimento "nos faz ver aquilo que uma época tem de intolerável, mas faz também emergir novas possibilidades de vida" (LAZZARATO, 2006, p. 12).

Somos intoleráveis à submissão dos corpos, aos moldes de um currículo petrificante de uma educação soberana quando não mais toleramos a servidão que nos foi imposta, e escapamos das garras de um sistema regulador, potencializados por currículos acontecimento que movimentam nossos corpos a resistir. "O acontecimento que emerge é por uma educação não soberana, não servil a tirania da dominação do pensamento" (GOMES; GOMES, 2018, p. 32).

A discussão em torno do currículo ainda se amplia ao pensarmos no contexto histórico das teorias de currículos e das intencionalidades políticas ao longo das teorias tradicionais, críticas e póscríticas. Dentre concepções que envolvem práticas mecânicas, subordinadas, práticas libertadoras, ideológicas, e a emergência de práticas por um viés pós-estruturalista, em um currículo das diferenças. Não pretendemos aqui reduzir o histórico curricular em tais características, nem dizer que a luta do currículo é só entre o prescrito e o praticado, mas sabemos que nenhuma prática é neutra e que em cada aposta, há uma questão de poder estabelecida.

Apostamos nos acontecimentos intoleráveis de um cotidiano escolar inventivo que perpassam os corpos de crianças e professores, estes que em "seus movimentos políticos, faziam mostragem de que o currículo não pode prestar aos serviços da vontade de verdade e de homogeneização" (GOMES; GOMES, 2018, p. 30). Para resistir, intoleramos, escapamos, criamos... "Resistir e criar. Essas são as possibilidades que nos abre o cotidiano da escola, quando escolhemos agir no fluxo dos acontecimentos" (GALLO, 2007, p. 39).

\section{MOVIMENTANDO OS CORPOS ENTRE CARTOGRAFIAS, CRIANÇAS, E CURRÍCULOS}

Queria tocar um lugar. Mas um lugar me toca. Não é um corpo que toquei ou qualquer outro corpo específico desse espaço, pois há, em torno de um corpo e de variados corpos, um universo intocável, que vive no entre, na relação entre coisas - entre salas de aula e recreios, entre um professor e um aluno, entre alunos, entre celulares e dedos ávidos por conexão, entre... (CARVALHO, 2019, p. 50). 
O que nos toca no movimento cartográfico de pesquisa são os encontros. Encontros com as crianças, com as imagens cinema, com o pensamento, com o currículo, com a docência,... Com subjetividades e experiências que compõem um corpo coletivo pelo qual se articula a pesquisa.

Desse modo, “a atenção do cartógrafo realiza uma exploração assistemática do terreno, com movimentos mais ou menos aleatórios de passe e repasse [...]. Tudo caminha até que a atenção, numa atitude de ativa receptividade, é tocada por algo" (KASTRUP, 2007, p. 19).

As crianças, em seus movimentos de pensamento, deslocam as imagens escola hierárquicas que tentam aprisionar os corpos, tocando outros possíveis, pois suas imagens são da ordem do impensado, do acontecimento. Distanciando-se das limitações prescritas que produzem movimentos mecânicos, em abertura de movimentos circulares que põe o corpo a girar. Como as cartografias que se seguem:

Uma manhã no parquinho... Como qualquer outro dia na Educação Infantil. As crianças nos convidam a brincar com elas. Entramos na brincadeira... Era a vez do gira-gira, ou roda-roda, como preferirem. As crianças não se importam com as nomenclaturas dos brinquedos, apenas se permitem brincar... Sentamos, colocamos os pés para dentro, as mãos posicionadas no brinquedo e lá vamos nós... Rodamos para um lado e para o outro... Era pra ser um momento de brincadeira, mas eis que surgiu um desafio: “Tia, agora vamos girar rápido!”. Para o nosso desespero, topamos participar... E em menos de um minuto girando, pedimos arrego: "Chega! Estamos tontas". Mas, as crianças insistiam, rodando incansavelmente, "Não, tia! O legal é ir rápido". 


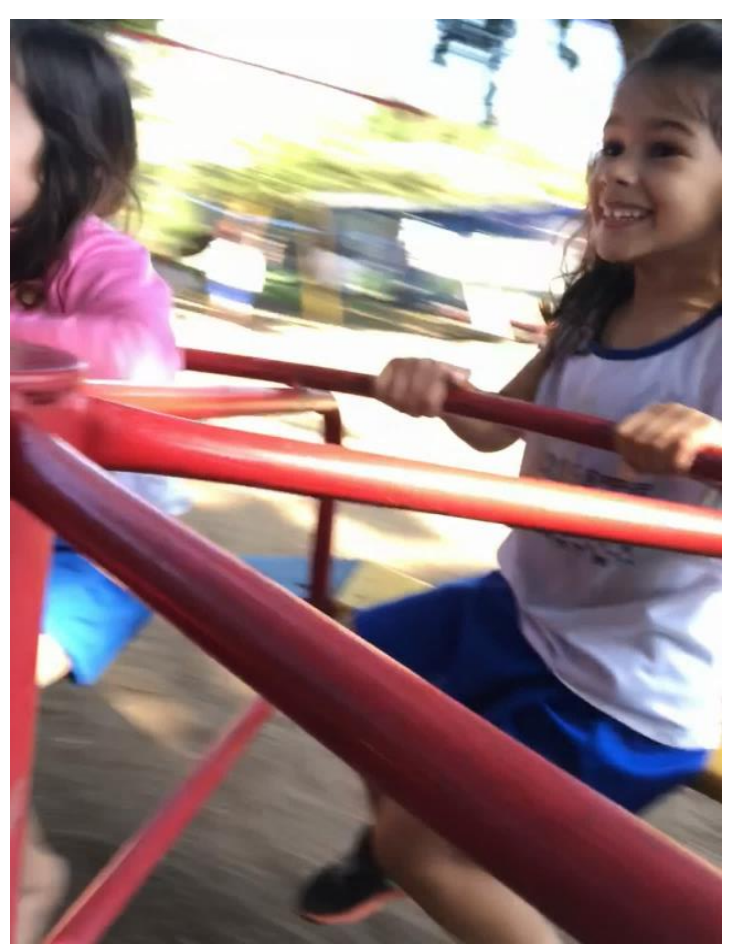

Imagem 2 - Currículos acontecimento que embalam os corpos. Fonte: arquivo pessoal.

Em alguns momentos, as linhas duras de pensamento interrompem a fluidez dos movimentos infantis. Práticas recognitivas que paralisam o fluxo inventivo dos corpos por um medo ou uma angústia que os tomam conta, pausando a brincadeira para recuperar suas forças:

"Eu não aguentei dois minutos rodando" - disse a professora atônita.

"Deus me livre! Parecia que a alma ia sair do corpo" - disse a pesquisadora enquanto sentava em um banco para descansar.

Aquilo que nos movimenta, que nos desafia, ou nos questiona, traz consigo um desconforto por nos distanciar do falso controle de nossos corpos. Mas, é possível controlar um acontecimento? De que modo damos passagem ao inusitado e os modelos são deslocados? O que nos dizem os corpos cansados? É possível a alma-invenção 'sair' do corpo-hábito? Como experimentar um tempo outro nos currículos?...

Não buscamos respostas a essas perguntas, nem nos interessa reduzi-las a uma explicação. O que desejamos é provocar o pensamento pela aposta nos currículos acontecimento. Estes não são medidos pela prescrição de um tempo determinado, mas por um tempo que dura nos sentidos. Os currículos são tempo intensivo, compostos por almas-corpos, movimentos circulares, territórios nômades, crianças, professores, gira-gira, parquinho, salas de aula, documentos, imagens cinema, pensamentos, fabulação,... 
Experimentamos currículos acontecimento fronteiriços. Mergulhamos entre propostas curriculares programadas por atividades, projetos e conteúdos, e naquilo que insurge na escola, nas práticas giratórias de crianças e professores em suas redes de ensino-aprendizagens coletivas. Não experimentamos para escolher, ou ditar uma preferência dentre as práticas, mas como buscando viver o campo de possibilidades que acontecem no território da Educação Infantil.

Assim, professores, pesquisadoras, crianças sacodiram as imagens escola girando os pensamentos em outros possíveis...

\footnotetext{
"Vocês não cansam?" - Perguntou a professora às crianças.

"Não. Vem girar com a gente de novo, tia!" - Insistiram as crianças rodando incessantemente.
}

Portanto, um currículo acontecimento produz sentidos, extrapola o previsto, irrompe o tempo e não lida com resultados mensuráveis, pois o "modo do acontecimento é a problematização. Um acontecimento não é a solução de problemas, mas a abertura de possíveis" (LAZZARATO, 2006, p. 13-14).

\section{CONSIDERAÇÕES GIRATÓRIAS DE PESQUISA...}

Crianças, professores, pesquisadora e equipe escolar envolveram seus corpos com a potência das imagens cinematográficas, deslizando imagens de pensamentos para além das imagens estanques que cercam a escola, movimentando imagens clichês, imagens reais, imagens imaginárias com os cotidianos escolares.

Buscamos cartografar os efeitos de pensamentos que emergiram nas experimentações infantis com o cinema; bem como entender que sentidos provocaram para a composição de territórios existenciais de currículos; problematizando as relações entre imagens cinema e crianças na abertura do campo dos possíveis.

Não buscamos encontrar respostas nem soluções para os currículos escolares, nem tampouco negar o currículo prescrito, mas "forçar o pensamento onde está o nosso limite de pensar" (LOURENÇO, 2015, p. 89), para além da imagem estanque que imobiliza a ação, apostando que os currículos acontecimento são "lugares de passagem, nada é definitivo, nada está capturado, tudo é paisagem mutante, é composição" (idem).

Sendo assim, é necessário evitar a mutilação da alegria de aprender, do prazer de criar nas salas de aula das escolas, e, nesse sentido, devemos explorar o currículo como 
um "acontecimento" vivido nele mesmo. O currículo muda à medida que nos envolvemos nele, refletimos sobre ele, consideramos sua complexidade tecida em rede de conversações [...] (CARVALHO, 2019, p. 60, grifo nosso).

Portanto, os acontecimentos diversos, experimentados com crianças e professores, nos fizeram perceber que a vida é insurgente quando desacostumamos nossos corpos às práticas reprodutivas, quando desejamos resistir àquilo que nos despotencializa, quando produzimos pensamentos com as crianças, quando nos movimentamos a viver uma vida imanente na Educação Infantil.

Assim, no desejo de não encerrar essa conversa a respeito dos currículos, deixaremos aqui um convite:

Por imagens escola deslizantes...

E corpos coletivos que escapam, rodam... E nunca param.

Pelos muros das normas e prescrições...

E os descaminhos de uma vida imanente...

Por crianças e professores...

$\mathrm{E}$ as rotas dos pensamentos nômades...

Pelos conhecimentos em redes...

E as pontes dos devires-alegria (CARVALHO, 2019)...

Por currículos acontecimento que movimentam os corpos...

E as cartografias de pesquisa...

Vamos atravessar as fronteiras dos territórios escolares? 


\section{REFERÊNCIAS}

BARROS, L. P.; KASTRUP, V. Cartografar é acompanhar processos. In: PASSOS, E.; KASTRUP, V.; ESCÓSSIA, L. (org.). Pistas do método da cartografia: pesquisa-intervenção e produção de subjetividade. Porto Alegre: Sulina, 2015.

BRASIL. Ministério da Educação. Base Nacional Comum Curricular. Brasília, DF: MEC, 2017.

CARVALHO, J. M. Macro/Micropolítica, cotidiano escolar e constituição de um corpo coletivo em devir. Revista Educação Temática Digital. Campinas, SP, v.21, n.1, p. 47-62, jan./mar. 2019. Disponível em: <https://periodicos.sbu.unicamp.br/ojs/index.php/etd/article/view/8650819/18996>. Acesso em: 13 mar. 2019.

CARVALHO, J. M. O cotidiano escolar como comunidade de afetos. Rio de Janeiro: DP\&A; Brasília, DF: CNPq, 2009.

CARVALHO, J. M.; SILVA, S. K. O cinema como linguagem potencializadora dos processos de aprender-ensinar. Leitura: Teoria \& Prática, Campinas, v.32, n.63, p.77-91, dez. 2014. Disponível em: <https://ltp.emnuvens.com.br/ltp/article/view/316>. Acesso em: 8 nov. 2017.

CERTEAU, M. A invenção do Cotidiano. As Artes de Fazer. Petrópolis: Vozes, 1996.

DELEUZE, G. Imagem-Tempo. 1985. Tradução de Eloisa de Araújo Ribeiro. Brasiliense. 1ª ed., 2007.

DELEUZE, G. Proust e os signos. Rio de Janeiro: Forense-Universitária, 1987.

DELEUZE, G.; GUATTARI, F. Mil platôs - capitalismo e esquizofrenia. Vol. 4. São Paulo: Ed. $54,1997$.

DELEUZE, G.; GUATTARI, F. Mil Platôs. Capitalismo e Esquizofrenia. Vol. 5. Rio de Janeiro: Ed. $34,2007$.

DIAS, R. O. Deslocamentos na formação de professores: aprendizagem de adultos, experiência e políticas de cognição. Rio de Janeiro: Lamparina, 2011.

FERRAÇO, C. E. Currículo-docência-menor e pesquisas com os cotidianos escolares. Quaestio - Revista de Estudos em $\begin{array}{llllllll}\text { Educação, } & \text { v. } 19, & \text { n. } & 3, & \text { p. } & 529-546, & 2017 . & \text { Disponível em: }\end{array}$ <http://periodicos.uniso.br/ojs/index.php/quaestio/article/view/3152>. Acesso em: 5 jun. 2019.

GALLO, S. Acontecimento e Resistência: educação menor no cotidiano escolar. In: CAMARGO, A. M. F.; MARIGUELA, M. (orgs.). Cotidiano escolar - emergência e invenção. Piracicaba: Jacintha Editores, 2007.

GOMES, L. F. R.; GOMES, H. J. S. De quem é o currículo? Problematizações por uma educação não soberana. Revista Teias. $\quad$ v. $\quad 19, \quad$ n. $\quad 55, \quad$ out./dez., $\quad 2018 . \quad$ Disponível $\quad$ em: $\quad<$ https://www.epublicacoes.uerj.br/index.php/revistateias/article/view/36067>. Acesso em: 25 mar. 2019.

KASTRUP, V. O funcionamento da atenção no trabalho do cartógrafo. In: PASSOS, E.; KASTRUP, V.; ESCÓSSIA, L. (org.). Pistas do método da cartografia: pesquisa-intervenção e produção de subjetividade. Porto Alegre: Sulina, 2015.

KASTRUP, V. O funcionamento da atenção no trabalho do cartógrafo. Psicologia \& Sociedade. 19(1): p. 15-22, jan./abr. 2007. Disponível em: <https://www.redalyc.org/pdf/3093/309326394003.pdf >. Acesso em: 18 abr. 2018.

LAZZARATO, M. As revoluções do capitalismo (A Política no Império). Rio de janeiro: Civilização Brasileira, 2006.

LOURENÇO, S. G. A força-invenção da docência e da infância nos processos de aprenderensinar. Vitória, UFES, 2015. Disponível em: <http://bdtd.ibict.br/vufind/Record/UFES_29c18c863c15e86a976c5b837bc72549 >. Acesso em: 21 jan. 2019.

RODRIGUES, L. F. Entre imagens cinema e imagens escola, movimentando o pensamento com a formação de professores. Vitória, UFES, 2015. Disponível em: 〈http://repositorio.ufes.br/handle/10/1818>. Acesso em: 21 jan. 2019.

ROLNIK, S. Cartografia sentimental: transformações contemporâneas do desejo. São Paulo: Estação Liberdade, 2007.

SANTOS, D. V.; DIAS, R. O. Invenção e formação de professores entre escritas e problematizações. In: LEMOS, F. C. S. et al. Criações transversais com Gilles Deleuze: artes, saberes e política. Curitiba: CRV, 2016.

TEBET, G. Desemaranhar as linhas da infância: elementos para uma cartografia. In: ABRAMOWICZ, A.; TEBET, G. (org.). Infância e Pós-estruturalismo. São Paulo: Porto de Idéias, 2017.

VASCONCELLOS, J. A filosofia e seus intercessores: Deleuze e a não-filosofia. Educ. Soc., Campinas, vol. 26, n. 93, p. 1217-1227, Set./Dez., 2005. Disponível em: 〈http://www.scielo.br/pdf/es/v26n93/27276.pdf〉. Acesso em: 4 fev. 2018. 


\section{CARTOGRAFIAS DE PESQUISA E CURRÍCULOS QUE MOVIMENTAM OS CORPOS NA EDUCAÇÃO INFANTIL}

Resumo: Objetiva entender em que sentido a produção de imagens cinema com crianças e professores provoca composição de territórios existenciais para os currículos na Educação Infantil. Busca outros possíveis para os processos curriculares, não para inová-lo, mas como uma abertura aos encontros. Portanto, questiona-se: Que imagens de currículos têm sido produzidas nas escolas? Usa como enfoque teórico-metodológico a pesquisa cartográfica com os cotidianos escolares de uma escola pública de Vitória/ES, e toma como estratégia metodológica as redes de conversações na constituição de um corpo coletivo de pesquisa. Por fim, aposta que o currículo é tecido nos múltiplos enredamentos que atravessam o território escolar, para além de uma representação fixa, na composição de currículos acontecimento.

Palavras-chave: Cartografia. Currículo. Educação Infantil.

\section{RESEARCH CARTOGRAPHS AND CURRICULUM MOVING BODIES IN CHILD EDUCATION}

Abstract: It aims to understand in what sense the production of cinema images with children and teachers causes the composition of existential territories for the curriculum in early childhood education. It looks for others possible for the curricular processes, not to innovate it, but as an opening to the meetings. Therefore, the question is: What curriculum images have been produced in schools? It uses as a theoretical and methodological approach the cartographic research with the school daily life of a public school in Vitória/ES, and takes as methodological strategy the networks of conversations in the constitution of a collective body of research. Finally, it bets that the curriculum is woven into the multiple entanglements that cross the school territory, beyond a fixed representation, in the composition of event curriculum.

Keywords: Cartograph. Curriculum. Child Education.

\section{CARTOGRAFÍAS DE INVESTIGACIÓN Y CURRÍCULOS QUE MUEVEN CUERPOS EN LA EDUCACIÓN INFANTIL}

Resumen: Su objetivo es comprender en qué sentido la producción de imágenes de cine con niños y maestros provoca la composición de territorios existenciales para los currículos en la educación infantil. Busca otros posibles para los procesos curriculares, no para innovar, sino como una apertura a las reuniones. Por lo tanto, la pregunta es: ¿qué imágenes curriculares se han producido en las escuelas? Utiliza como enfoque teórico y metodológico la investigación cartográfica con la vida diaria escolar de una escuela pública en Vitória/ES, y toma como estrategia metodológica las redes de conversaciones en la constitución de un cuerpo colectivo de investigación. Finalmente, apuesta que el currículo está entretejido en los múltiples enredos que cruzan el territorio escolar, más allá de una representación fija, en la composición de los currículos de eventos.

Palavras clave: Cartografía. Currículo. Educación Infantil.

Submetido em Agosto de 2019

Aprovado em Dezembro de 2019

Revista Teias v. $20 \bullet$ n. 59 • out/dez 2019 • Outras epistemologias e metodologias nas investigações sobre currículo 138 